\title{
PERLINDUNGAN HUKUM KONTRAK DALAM PERSPEKTIF HUKUM KONTRAK KONTEMPORER
}

\author{
M. Natsir Asnawi \\ Pengadilan Agama Banjarbaru \\ Jalan Trikora No.4 Kota Banjarbaru, Kalimantan Selatan \\ natsirasnawi@rocketmail.com
}

\begin{abstract}
There are two main doctrine in contract law, classical and contemporary doctrine. The classical doctrin emphasize the legal certainty to be the core of legal issue in contract law. The doctrine noted that every single purpose of parties should be stated in contract in order to put binding effect to the parties. It also distinguish the concept of breach of contract and tort. The petition for breach of contract should be based on the concept of breach of contract instead tort. In reverse, the contemporary doctrine emphasize the justice and appropriateness aspect in a contract. It recognized the contract as the whole process held by pre-contractual phase, contractual phase, and postcontractual phase. Hence, it realize the existence of impact toward promises stated by one party to others which is distinctly different to the classical doctrine that neglect the impact of precontractual. The contemporary doctrine eliminates the distinguishing of breach of contract and tort as the basic of the sue because breach of contract was the specific genus of tort.
\end{abstract}

Keywords: legal doctrine, contract law, per-contractual, justice.

\begin{abstract}
Abstrak
Doktrin hukum pada prinsipnya terbagi atas dua, yaitu doktrin klasik dan doktrin kontemporer. Doktrin hukum kontrak klasik menekankan pada aspek kepastian hukum. Aspek ini tergambar dari penekanannya bahwa setiap pernyataan kehendak harus dituangkan dalam kontrak yang ditandatangani para pihak agar memiliki kekuatan mengikat. Doktrin klasik membedakan secara tegas wanprestasi dan perbuatan melawan hukum. Tuntutan atas pelanggaran kontrak harus dengan dasar wanprestasi, bukan perbuatan melawan hukum. Sebaliknya, doktrin kontemporer lebih menekankan pada aspek keadilan dan kepatutan. Doktrin kontemporer mengenal kontrak sebagai konstruksi yang terdiri atas tahap pracontractual, contractual, dan postcontractual. Karenanya, doktrin kontemporer menganggap janji-janji pra kontrak memiliki akibat hukum tertentu, hal mana berbeda dengan doktrin klasik yang tidak mengakui adanya akibat hukum pra kontrak. Doktrin kontemporer juga tidak lagi membedakan secara tegas wanprestasi dan perbuatan melawan hukum sebagai dasar gugatan pelanggaran kontrak karena wanprestasi pada prinsipnya merupakan specific genus dari perbuatan melawan hukum.
\end{abstract}

Kata kunci: doktrin hukum, hukum kontrak, pra kontrak, keadilan

\section{A. Pendahuluan}

1. Latar Belakang Permasalahan

Manusia adalah makhluk sosial. Eksistensinya terangkum dalam suatu jagat sosial yang mempersyaratkan interaksi dengan sesamanya. Interaksi antar sesama manusia melahirkan dinamika-dinamika yang sedikit banyak terkait dengan pembuatan suatu perjanjian (kontrak), baik perjanjian yang bersifat ekonomis (dalam bidang perniagaan) maupun perjanjian non ekonomis, misalnya dalam perjanjian pengerjaan suatu proyek sosial keagamaan.

Interaksi yang terwujud dalam suatu perjanjian yang disepakati oleh dua pihak atau lebih lahir dari adanya kebutuhan saling melengkapi satu sama lain. Kodrat manusia adalah ia tidak dapat hidup sendiri, melainkan 
membutuhkan bantuan atau keterlibat pihak lain dalam mewujudkan tujuan-tujuan hidupnya. Secara primordial, manusia telah mempraktikkan perjanjian-perjanjian sederhana dalam kerangka pemenuhan kebutuhan sehari-hari, misalnya pertukaran barang (goods exchange).

Pada praktiknya, dalam membuat dan melaksanakan suatu perjanjian yang melahirkan kontrak (perikatan), sering kali ditemukan permasalahan. Permasalahan dalam kontrak dapat muncul ketika salah satu pihak tidak menjalankan suatu prestasi atau kewajiban sesuai dengan yang disepakati atau adanya perselisihan mengenai makna-makna redaksi dalam kontrak. Permasalahan yang berakar dari dua hal tersebut sering menimbulkan kerugian pada salah satu atau kedua belah pihak. Pada titik inilah terjadi persengketaan antara pihak-pihak yang mengikatkan diri pada kontrak tersebut.

Hukum kontrak sebagai bagian dari hukum perdata mengalami perkembangan yang demikian pesat. Salah satu aspek yang sangat menonjol dalam perkembangan hukum kontrak adalah doktrin hukum kontrak. Dalam konteks studi ilmiah hukum kontrak, doktrin hukum kontrak dapat dibedakan menjadi dua, yaitu doktrin klasik dan doktrin kontemporer. Doktrin hukum kontrak klasik lebih menekankan pada dimensi normatif dari hukum kontrak. Karakteristik dari doktrin klasik adalah mempertahankan status quo aturan dan/atau kaidah hukum sekalipun konteks perkara telah berubah. Sementara itu, doktrin kontemporer menekankan pada upaya menegakkan keadilan substantif, alih-alih terjebak dalam status quo keadilan prosedural. Untuk menegakkan keadilan substantif, aturan dan/atau kaidah hukum yang dianggap membelenggu ditinggalkan dan beralih kepada penerapan hukum yang mengedepankan pendekatan kontekstual. Di sini, ruang kebebasan berpikir para yuris maupun para pihak mendapatkan tempatnya, karena penekanannya adalah bagaimana menegakkan keadilan substantif.

Isu terpenting dalam perlindungan hukum kontrak adalah bagaimana memulihkan hak-hak para pihak yang dirugikan. Menjawabnya ternyata tidak sesederhana yang dibayangkan. Banyak konsep berkeliaran dalam hukum kontrak yang masing-masing memiliki konteks dan implikasi berbeda, misalnya konsep perbuatan melawan hukum, wanprestasi, keadaan memaksa (force majeur), asas-asas perikatan, dan sebagainya. Makalah ini berupaya memaparkan, sejauh kemampuan penulis, secara komprehensif konsep perlindungan hukum dalam hukum kontrak.

Sesuai dengan judul makalah ini, penulis merumuskan beberapa permasalahan sebagai berikut:

1. Doktrin hukum dalam hukum kontrak;

2. Perlindungan hukum kontrak dalam perspektif hukum kontrak kontemporer;

\section{Kerangka Teori \\ a. Definisi kontrak (perikatan)}

Istilah kontrak atau perikatan (overenkomst) sering dipadankan dengan perjanjian (verbintenissen). Sekalipun memiliki perbedaan dari sisi makna etimologis, namun dalam tataran operasional, ketika menyebut perjanjian maka konotasinya adalah kontrak atau perikatan. Ini dapat dimaklumi karena perjanjian sebenarnya merupakan alasan atau dasar adanya kontrak. Makalah ini tidak untuk mempertentangkan kedua hal itu, karenanya, ketika menyebut istilah kontrak atau perikatan, maka terkandung pula makna perjanjian, vice versa.

Perjanjian dalam bahasa Inggris disebut dengan contract. Kata contract dalam Black's Law Dictionary didefinisikan sebagai berikut:

"A promissory agreement between two or more persons that creates, modifies, or destroys a legal relation" (Henry Campbell Black, 1968).

Definisi tersebut menekankan bahwa suatu perjanjian (contract) merupakan persetujuan perjanjian antara dua pihak atau lebih. Suatu persetujuan yang diperjanjikan membawa akibat hukum pada lahir, berubah, atau berakhirnya suatu hubungan hukum. Definisi ini lebih menekankan pada akibat dari suatu persetujuan.

Perikatan yang lahir dari perjanjian (Untuk menyederhanakan penyebutan), diatur dalam Buku III KUHPerdata Pasal 1313 1351. Pengaturan mengenai perjanjian dalam 
Buku III tersebut mencakup:

a. Ketentuan umum (Pasal 1313-1319);

b. Syarat sah perjanjian (Pasal 1320 1337);

c. Akibat perjanjian (Pasal 1338-1341);

d. Penafsiran perjanjian (Pasal 1342 1351).

Pada umumnya, untuk mendefinisikan perjanjian, acuan utamanya adalah Pasal 1313 KUHPerdata. Menurut Pasal 1313 KUHPerdata, perjanjian adalah:

"Suatu persetujuan adalah suatu perbuatan dimana satu orang atau lebih mengikatkan diri terhadap satu orang lain atau lebih"

Definisi perjanjian dalam Pasal 1313 tersebut di atas dikritik oleh Subekti. Definisi tersebut mengaburkan makna esensial perjanjian karena Pasal 1313 seolah-olah mendefinisikan perjanjian sebagai perbuatan sepihak padahal secara umum perjanjian merupakan perbuatan timbal balik dari para pihak yang mengikatkan diri di dalamnya (Suharnoko,. Dalam perjanjian jual beli misalnya, maka perjanjian jual beli merupakan perjanjian yang mengandung perbuatan secara timbal balik, yaitu penjual melakukan penjualan barang atau jasa tertentu dan pembeli melakukan pembelian dengan membayar sejumlah uang atau alat pembayaran lainnya.

Masih dalam definisi yang bersifat normatif, perjanjian dalam hukum Islam disebut aqd atau akad. Pasal 20 Angka (1) Peraturan Mahkamah Agung RI Nomor 2 Tahun 2008 tentang Kompilasi Hukum Ekonomi Syariah menyatakan:

"Akad adalah kesepakatan dalam suatu perjanjian antara dua pihak atau lebih untuk melakukan dan/atau tidak melakukan perbuatan hukum tertentu" (Kompilasi Hukum Ekonomi Syariah).

Perjanjian menurut Riduan Syahrani adalah hubungan hukum antara dua pihak di dalam lapangan harta kekayaan dimana salah satu pihak bertindak sebagai kreditur yang berhak atas prestasi (kewajiban) tertentu dan pihak lain sebagai debitur berkewajiban memenuhi prestasi tersebut (Riduan Syahrani, 2006). Salim HS, dkk, mendefinisikan perjanjian sebagai hubungan hukum antara subjek hukum yang satu dengan subjek hukum yang lain dalam bidang harta kekayaan, dimana satu subjek hukum berhak atas prestasi dan subjek hukum lainnya berkewajiban untuk melaksanakan prestasi tersebut sesuai dengan kesepakatan di antara mereka (Salim HS, 2008).

M. Yahya Harahap mendefinisikan perjanjian sebagai suatu hubungan hukum kekayaan atau harta benda antara dua orang (pihak) atau lebih yang member kekuataan hak pada satu pihak untuk memperoleh prestasi dan sekaligus mewajibkan pihak lain untuk menunaikan prestasi tersebut. Definisi tersebut menggambarkan bahwa dalam suatu perjanjian ada beberapa unsur membangunnya, yaitu 1) hubungan hukum; 2) hak; dan 3) kewajiban (prestasi). Hubungan hukum dalam perjanjian adalah hubungan hukum yang dikehendaki para pihak, bukan hubungan hukum yang lahir dengan sendirinya atau lahir karena adanya undang-undang. Sebagai contoh, hubungan hukum dalam harta benda kekeluargaan. Dalam hubungan hukum harta benda keluarga, dengan sendirinya timbul hubungan hukum antara anak dengan kekayaan orang tuanya sebagaimana diatur dalam hukum waris, baik hukum waris Islam maupun hukum waris perdata barat (M. Yahya Harahap, 1968).

Hubungan hukum yang lahir dari suatu perjanjian adalah hubungan hukum yang dikehendaki. Adanya hubungan hukum tersebut didahului dengan suatu tindakan hukum (rechtshandeling). Hubungan hukum dalam perjanjian adalah hubungan timbal balik antara hak dan kewajiban pada masingmasing pihak (M. Yahya Harahap, 1968). Penulis menyebutnya sebagai hubungan resiprokal dalam perjanjian, hak pada salah satu pihak menjadi kewajiban pada pihak lainnya, viceversa.

\section{b. Asas-asas kontrak (perikatan)}

Dalam perjanjian, termuat beberapa asas yang menjadi landasan suatu perjanjian. Asas tersebut merupakan pedoman bagi para pihak dalam melakukan suatu perjanjian, sehingga perjanjian yang dibuat memiliki kekuatan mengikat bagi para pihak yang membuat perjanjian. KUHPerdata menetapkan beberapa asas dalam perjanjian sebagai koridor bagi para pihak yang 
membuat perjanjian hingga menjadi suatu perikatan yang dapat dipaksakan pelaksanaan atau pemenuhannya. Asas-asas dalam perjanjian tersebut adalah:

a. Asas personalia

Asas personalia dapat ditemukan dalam ketentuan dalam ketentuan pasal 1315 KUHPerdata yang menyatakan bahwa "pada umumnya tak seorangpun dapat mengikatkan diri atas nama sendiri atau meminta ditetapkannya suatu janji selain untuk dirinya sendiri". Berdasar rumusan tersebut, dapat diketahui bahwa pada dasarnya perjanjian yang dibuat oleh seseorang sebagai subjek hukum hanya berlaku untuk dirinya sendiri. Secara spesifik, ketentuan tersebut menunjuk pada kewenangan bertindak sebagai individu pribadi untuk bertindak atas namanya sendiri (Kartini Muljadi \& Gunawan Widjaja, 2003).

\section{c. Asas konsensualitas}

Substansi asas konsensualitas adalah pada dasarnya suatu perjanjian yang dibuat secara lisan antara dua pihak atau lebih telah mengikat dan karena itu melahirkan kewajiban bagi salah satu pihak atau lebih dalam perjanjian tersebut setelah para pihak mencapai kesepakatan. Berdasar asas ini, perjanjian yang mengikat dan berlaku sebagai perikatan bagi para pihak yang berjanji tidak memerlukan formalitas.

\section{d. Asas kebebasan berkontrak}

Asas ini mengatur ketentuan bahwa pada dasarnya para pihak dapat membuat perjanjian atau kesepakatan yang melahirkan kewajiban apa saja sepanjang prestasi yang wajib dilakukan tersebut bukanlah sesuatu yang terlarang. Ketentuan pasal 1337 menyebutkan "Suatu sebab adalah terlarang, apabila dilarang oleh undang-undang, atau apabila berlawanan dengan kesusilaan baik atau ketertiban umum". Ketentuan tersebut memberikan gambaran bahwa pada dasarnya semua perjanjian dapat dibuat dan diselenggarakan oleh setiap orang. Perjanjian yang dilarang adalah perjanjian yang mengandung prestasi atau kewajiban pada salah satu pihak yang melanggar undangundang atau kesusilaan (Kartini Muljadi \& Gunawan Widjaja, 2003).

\section{e. Asas pacta sunt servanda}

Asas ini diatur dalam pasal 1338 ayat

(1) KUHPdt yang menyatakan bahwa
"Semua perjanjian yang dibuat secara sah berlaku sebagai undang-undang bagi mereka yang membuatnya". Berdasar ketentuan tersebut, maka dapat dipahami bahwa perjanjian yang telah dibuat secara sadar dan berdasar atas kesepakatan masing-masing pihak merupakan undang-undang (peraturan) yang mengikat masing-masing pihak yang membuat perjanjian tersebut.

\section{f. Wanprestasi}

Wanprestasi adalah suatu keadaan dimana pihak-pihak atau salah satu pihak tidak memenuhi prestasi sebagaimana yang telah ditentukan dalam perjanjian (Riduan Syahrani, 200). Dalam bahasa yang lebih sederhana, wanprestasi adalah kelalaian pihak atau salah satu pihak untuk menjalankan kewajiban-kewajibannya (prestasi) seperti yang tertuang dalam butirbutir perjanjian yang telah disepakati.

Kelalaian atau tidak dipenuhinya kewajiban dimaksud merupakan condition sine qua non bagi dikualifikasinya satu pihak melakukan wanprestasi. Pasal 1234 KUHPdt menyatakan:

"Perikatan ditujukan untuk memberikan sesuatu, untuk berbuat sesuatu, atau untuk tidak berbuat sesuatu"

Berdasar klausul pasal tersebut, dapat dipahami bahwa dalam suatu perikatan (yang lahir dari perjanjian maupun karena ditetapkan undang-undang) melahirkan pretasi-prestasi atau kewajiban-kewajiban yang mewujud, sebagai berikut:

a. Kewajiban untuk memberikan sesuatu oleh satu pihak kepada pihak lain

b. Kewajiban untuk melakukan suatu perbuatan (hukum) wujud dan kualitasnya telah disepakati bersama

c. Kewajiban untuk tidak melakukan suatu perbuatan, termasuk di dalamnya untuk menghentikan suatu perbuatan

Dari penjelasan atas pasal tersebut, dapat diketahui bahwa jika salah satu atau beberapa pihak tidak melakukan salah satu dari tiga kualifikasi kewajiban tersebut, maka dapat dikatakan bahwa telah terjadi wanprestasi atau cidera janji yang menyebabkan adanya hak yang tidak terpenuhi pada pihak lain. Terjadinya 
wanprestasi perlu dipahami secara menyeluruh bahwa tidak semua keadaan dimaksud menyebabkan satu pihak terkualifikasi melakukan wanprestasi. Dalam keadaan tertentu, kualifikasi terhadap keadaan tersebut tidak masuk ke dalam kategori wanprestasi, antara lain:

a. Overmacht, sering disebut sebagai force majeure, yaitu keadaan memaksa (Riduan Syahrani, 2006). Keadaan memaksa dapat dimaknai secara lebih luas sebagai suatu keadaan yang memaksa salah satu atau beberapa pihak tidak dapat memenuhi kewajiban-kewajibannya sebagai disepakati dalam perikatan yang telah dibuat, dan keadaan tersebut diluar prediksi, kendali, maupun kemampuannya secara fisik, psikis, maupun teknis.

b. Rechtsverwerking (Pengaturan tentang rechtsverwerking), yaitu lepasnya satu atau beberapa pihak dari kewajiban tertentu, karena pihak lain, baik secara diam, lisan, maupun tertulis membebaskan atau disimpulkan membebaskan yang bersangkutan dari kewajiban dimaksud (Riduan Syahrani, 2006).

c. Non adimpleti contractus, yaitu tidak dipenuhinnya janji atau kewajiban oleh salah satu atau beberapa pihak karena pihak lain yang terikat dalam perjanjian dimaksud juga tidak melaksanakan kewajiban-kewajiban atau janjijanjinya. Non adimpleti contractus ini dalam pemeriksaan perkara perdata sering dijadikan sebagai alasn untuk mengajukan keberatan atau eksepsi terhadap gugatan wanprestasi yang diajukan. Dalam jargon hukum acara perdata, eksepsi tersebut jamak dikenal dengan istilah exceptio non adimpleti contractus.

Terjadinya wanpretasi atau sidera janji (breach of contract) dalam suatu perikatan dapat berupa:
a. Sama sekali tidak memenuhi atau melaksanakan prestasi (kewajiban);
b. Tidak melaksanakan prestasi secara

menyeluruh; tidak menyelesaikan semua kewajiban yang telah disepakati;

c. Terlambat memenuhi atau melaksanakan prestasi;

d. Salah dalam melaksanakan prestasi (Riduan Syahrani, 2006).

\section{g. Perbuatan melawan hukum}

Istilah perbuatan melawan hukum (onrechtmatigedaad) dalam bahasa Belanda lazimnya mempunyai arti yang sempit, yaitu arti yang dipakai dalam Pasal 1365 Burgerlijk Wetboek (BW). Untuk selanjutnya akan digunakan istilah Kitab Undang-Undang Hukum Perdata (KUHPerdata) sebagai pengganti BW. Pasal ini diartikan berbedabeda di antara ahli hukum, ada yang mengartikannya sebagai Perbuatan Melanggar Hukum dan ada pula yang mengartikannya sebagai Perbuatan Melawan Hukum. Pasal 1365 KUHPerdata selengkapnya berbunyi:

"Als onrechtmatige daad worden aangemerkt een inbreuk op een recht en een doen of nalaten in strijd met een wettelijke plichtof met hetgeen volgens ongeschreven recht in het maatschappelijk verkeer betaamt, een ander behoudens de aanwezigheid van een rechtvaardigingingsgrond"

Salah satu perkembangan penting dalam konsep perbuatan melawan hukum adalah perluasan makna perbuatan melawan hukum dalam Pasal 1365 KUHPerdata. Jika pada awalnya perbuatan melawan hukum hanya perbuatan yang melanggar undang-undang, maka setelah tahun 1919 perbuatan melawan hukum diperluas maknanya. Putusan Hoge Raad tahun 1919 dalam perkara antara Lindenbaum melawan Cohen memperluas makna perbuatan melawan hukum sebagai perbuatan yang tidak hanya melanggar undang-undang. Perbuatan melawan hukum adalah berbuat atau tidak berbuat yang:

a. Melanggar hak subjektif orang lain (hak yang ditentukan undang-undang);

b. Bertentangan dengan kewajiban hukum si pelaku (kewajiban yang ditentukan undang-undang); atau

c. Bertentangan dengan tata susila atau bertentangan dengan kepatutan, ketelitian, dan kehati-hatian yang seharusnya dimiliki seseorang dalam 
pergaulan dengan sesame warga masyarakat atau terhadap harta benda orang lain (Suharmoko, 2008).

Putusan Hoge Raad tersebut kemudian menjadi patron bagi pengadilan-pengadilan di Belanda, tidak terkecuali di Indonesia. Pemahaman tentang perbuatan melawan hukum tidak lagi dapat dipandang sebagai hanya melanggar hukum saja, tetapi perbuatan yang melanggar hak dan kewajiban hukum serta kepatutan dalam msyarakat. Dengan demikian, hemat penulis, dapat dipahami bahwa substansi perbuatan melawan hukum adalah perbuatan yang menimbulkan kerugian nyata pada pihak lain, dengan tidak memperhatikan variabel hukum apa yang dilanggarnya.

\section{h. Perlindungan hukum}

Perlindungan hukum merupakan elemen mendasar dalam hukum. Ia berkenaan dengan upaya menegakkan dan memulihkan hak-hak keperdataan subjek hukum tertentu. Karenanya, perlindungan hukum dapat dimaknai sebagai upaya untuk menegakkan dan/atau memulihkan hak-hak keperdataan subjek hukum tertentu.

Wahyu Sasongko mendefinisikan perlindungan hukum sebagai suatu tindakan perlindungan atau tindakan melindungi pihak-pihak tertentu yang ditujukan untuk pihak tertentu dengan menggunakan caracara tertentu. Dari definisi itu, maka ada tiga unsur dalam perlindungan hukum, yaitu:
a. Unsur tindakan melindung;
b. Unsur pihak yang melindungi;
c. Unsur cara atau mekanisme melindungi.
(Wahyu Sasongko, 2007)

Konsep perlindungan hukum sebenarnya merupakan konsep yang telah lama dikenal dalam studi hukum. Karena pada dasarnya dalam setiap hubungan keperdataan berpotensi memunculkan permasalahan, maka konsep perlindungan hukum merupakan condition sine qua non dalam konsep hukum perdata. Perlindungan hukum melibatkan banyak sarana dan pranata hukum. Sarana hukum yang digunakan dalam perlindungan hukum antara lain adalah perundang-undangan, selain tentunya asasasas hukum yang berkaitan dengan hukum perdata. Perundang-undangan dan asas-asas hukum merupakan patronase dalam melindungi kepentingan-kepentingan hukum para pihak yang terikat dalam suatu perjanjian. Perundang-undangan dan asasas as hukum ini yang kemudian diimplementasikan oleh pranata-pranata hukum yang ada, misalnya Pengadilan sebagai pemutus perkara atau lembaga penyelesaian sengketa di luar Pengadilan (alternative dispute resolution).

\section{B. Pembahasan \\ 1. Doktrin hukum kontrak}

Doktrin hukum adalah pendapatpendapat yang dikemukakan oleh para pakar hukum yang mengandung kaidah-kaidah hukum tertentu dan dipedomani oleh para Yuris (Hakim) dalam memutus perkara maupun oleh akademisi hukum dalam meneliti dan mengembangkan pemahaman mengenai hukum. Bahwa memang tidak semua doktrin dapat dikategorikan sebagai doktrin hukum, namun menjadi kesepakatan bahwa doktrin hukum menjadi penting sebagai salah satu sumber hukum yang penting (Achmad Ali, 1996).

Hukum kontrak sebagai bagian dari hukum perdata merupakan salah bidang hukum yang kompleks. Kompleks karena di dalamnya terkandung banyak pengaturan mengenai dinamika kontrak (perjanjian) dan terbukanya ruang penafsiran bagi perancangan, pembuatan, dan pelaksanaan suatu perjanjian.

Doktrin hukum kontrak pada dasarnya dapat dikulaifikasikan menjadi dua, yaitu doktrin lama dan doktrin baru (Bandingkan dengan Salim HS). Doktrin hukum kontrak yang lama menekankan kontrak atau perjanjian dari sisi normatif, dalam hal ini kepastian hukum. Doktrin hukum kontrak yang lama melihat kontrak sebagai satu konstruksi yang di dalamnya mengandung consideration (kewajiban, prestasi) dan hak (rights) para pihak yang mengikatkan diri di dalamnya. Doktrin lama tidak mengakui tahapan-tahapan pra kontrak sebagai kontrak itu sendiri atau setidak-tidaknya sebagai sebuah kesepahaman yang mengikat dan melahirkan hak dan kewajiban.

Sementara itu, doktrin hukum kontrak kontemporer melihat kontrak dalam 
perspektif yang lebih luas. Salim HS dkk mengemukakan bahwa jika mengacu pada definisi perjanjian yang dikemukakan Van Dunne bahwa perjanjian merupakan suatu hubungan hukum antara dua pihak atau lebih berdasarkan kesepakatan untuk menimbulkan akibat hukum, maka doktrin kontemporer melihat perjanjian dalam pengertian an sich semata, melainkan perbuatan-perbuatan sebelumnya atau yang mendahuluinya (Bandingkan dengan Salim HS).

Doktrin kontemporer telah mengintrodusir adanya tiga tahapan dalam membuat suatu perjanjian, yaitu:

a. Tahap pracontractual, yaitu proses tawar-menawar atau negosiasi oleh pihak-pihak yang akan mengikatkan diri dalam perjanjian;

b. Tahap contractual, yaitu adanya persesuaian pernyataan kehendak dari para pihak yang mengikatkan diri dalam perjanjian;

c. Tahap postcontractual, yaitu pelaksanaan perjanjian oleh para pihak dengan dilandasi iktikad baik (Bandingkan dengan Salim HS).

Salah satu definisi yang pernah dikemukakan terkait dengan doktrin kontemporer adalah definisi yang dikemukakan oleh Charles M. Knapp dan Nathan M. Crystal, sebagaimana dikutip oleh Salim HS dkk (Bandingkan dengan Salim HS). Charles M. Knapp dan Nathan M. Crystal mendefinisikan kontrak (contract) sebagai berikut:

"an agreement between two or more persons - not merely a shared belief, but common understanding as to something that is to be done in the future by one or both of them"

Terjemahan bebas:

"persetujuan di antara dua pihak atau lebih, persetujuan yang tidak hanya melibatkan kepercayaan di antara mereka, namun juga kesepahaman mengenai hal-hal yang diperjanjikan dan dilaksanakan pada masa yang akan datang, baik oleh salah satu pihak maupun kedua belah pihak"

Definisi tersebut membawa perubahan perspektif dalam memahami perjanjian. Definisi demikian menyebabkan tahapan- tahapan pra kontrak (preliminary negosiation) yang di dalamnya terkandung janji-janji (promissory) mengikat dan membawa akibat hukum bagi para pihak yang melakukan negosiasi. Sejalan dengan hal tersebut, Suharnoko (Suharnoko, 2008) menegaskan bahwa doktrin hukum kontrak modern cenderung menghapuskan syaratsyarat formil bagi kepastian hukum dan lebih menekankan terpenuhinya rasa keadilan. Jika dalam tahap pra kontrak salah seorang pihak mengundurkan tanpa alasan yang dapat dibenarkan menurut hukum atau menurut kepatutan dan menimbulkan kerugian pada pihak lainnya, maka hal itu membawa akibat hukum bagi pihak yang mengundrukan diri dan wajib mengganti kerugian yang diderita pihak lainnya.

Pengadilan di Amerika Serikat telah mengembangkan doktrin promissory estoppel untuk mengatasi situasi dimana perjanjian belum memenuhi syarat formil tertentu (misalnya syarat mengenai hal tertentu atau objek tertentu), tetapi salah satu pihak karena percaya dan menaruh harapan kepada janji-janji yang diberikan pihak lawan dalam proses negosiasi melakukan perbuatan hukum tertentu, seperti melakukan investasi atau penanaman modal sebagai syarat pendahuluan dari akan disepakatinya suatu perjanjian di antara mereka. Implementasi doktrin promissory estoppel dapat dilihat misalnya dalam kasus Hoffman melawan Red Owl Stores (1965) 26 Wis.2d.683,133 NW.2d.267. Dalam kasus tersebut, para pihak merundingkan tentang kemungkinan pemberian franchise dari Tergugat suatu perusahaan supermarket yang mengoperasikan beberapa toko di berbagai wilayah kepada Penggugat. Dalam proses perundingan, Tergugat berjanji akan membangun toko di Chilton dan mengisinya dengan barang-barang dagangan untuk dijual oleh Hoffman jika Hoffman bersedia menginvestasikan uang sebesar USD 18.000. Karena percaya dengan janji tersebut, maka Penggugat (Hoffman) membeli sebuah bangunan di Chilton dan menyewa rumah tempat tinggal untuk dirinya beserta keluarganya di Chilton. Akan tetapi, kemudian Tergugat menarik janjinya dan meminta jumlah investasi yang lebih besar 
dan Hoffman menyatakan tidak sanggup memenuhi permintaan tersebut yang pada akhirnya kontrak franchise yang dinegosiasikan sebelumnya tidak terwujud. The Wisnoncin Supreme Court mengadopsi pandangan hukum kontrak modern dengan mengabaikan syarat kepastian hukum demi mencapai keadilan yang substansial dan memutuskan bahwa Penggugat berhak mendapatkan ganti atas kerugian yang dideritanya karena percaya dan menaruh pengharapan pada janji-janji Penggugat untuk memberikan kontrak waralaba (franchise contract) (Suharnoko, 2008).

Hal menarik dalam putusan tersebut adalah penggantian kerugian yang ditetapkan Pengadilan adalah kerugian nyata (reliance loss) dikarenakan tidak adanya iktikad baik dari Tergugat yang telah memberikan janji kepada Penggugat dalam perundingan kontrak waralaba (franchise contract). Pengadilan menetapkan ganti rugi bukan atas ganti hilangnya keuntungan yang diharapkan (expectation loss) namun kerugian nyata (reliance loss) dikarenakan secara normatif memang belum ada perjanjian, namun secara faktual ada suatu perbuatan yang bertentangan dengan kepatutan, yaitu dilanggarnya janji-janji yang telah disampaikan dan karena janji itu pihak lain mengharapkan sesuatu namun tidak dipenuhi dan timbullah kerugian nyata pada pihak yang dijanjikan (Suharnoko, 2008).

Doktrin hukum kontrak kontemporer tampaknya ingin menjembatani jurang yang memisahkan antara consideration dalam perjanjian dengan promissory atau janji-janji dalam pra kontrak. Consideration adalah prestasi tertentu yang disepakati oleh para pihak dalam perjanjian (Suharnoko, 2008). Consideration kepustakaan hukum nasional, consideration dikenal istilah prestasi dan jika mengacu pada Pasal 1320 KUHPerdata, maka consideration dipadankan maknanya dengan "objek tertentu" yang diperjanjikan para pihak. Tidak adanya kekuatan normatif dari suatu perjanjian yang mendasari suatu janji atau promise diatasi dengan kehendak mewujudkan keadilan substantif atas kerugian yang diderita oleh pihak yang dijanjikan, alih-alih terpaku pada prinsip kepastian hukum yang kaku dan tidak mampu mengakomodir perkembangan (dinamika) dalam hukum kontrak modern.

\section{Perlindungan hukum kontrak dalam perspektif hukum kontrak kontemporer}

a. Perlindungan hukum terhadap perjanjian

Hukum perdata Indonesia mengenal dua jenis perikatan, yaitu perikatan yang lahir dari perjanjian dan perikatan yang lahir karena ditetapkan oleh undang-undang. Perikatan yang lahir dari perjanjian merupakan perikatan yang lahir dari upaya sadar dari dua pihak atau lebih untuk mengikatkan diri dalam suatu perjanjian dengan memperhatikan syarat-syarat sah suatu perjanjian sebagai diatur dalam pasal 1320 KUHPdt. Sementara itu, perikatan yang lahir karena ditetapkan oleh undang-undang adalah perikatan yang lahir karena undangundang menetapkan itu, antara lain onrechtmatigedaad (perbuatan melawan hukum) dan rechtmatigedaad (perbuatan yang sesuai dengan hukum) yang meliputi zaakwarneming (mewakili secara sukarela untuk mengurus urusan orang lain), natuurlijke verbintenis (perikatan alam), dan onverschuldigde betaling (pembayaran yang tidak diwajibkan) (Ketentuan mengenai hal tersebut dapat dilihat dalam Pasal 1233).

Sengketa perdata dapat dipahami sebagai suatu keadaan yang muncul akibat adanya ketimpangan antara hak dan kewajiban pihak-pihak yang terlibat dalam suatu perikatan/perjanjian. Sengketa muncul, selain karena adanya ketimpangan antara hak dan kewajiban dimaksud, juga disebabkan karena salah satu pihak tidak sungguhsungguh menaati dan melaksanakan isi perjanjian, sehingga menimbulkan kerugian bagi pihak lain, baik yang bersifat kerugian nyata (real loss) maupun hilangnya keuntungan yang diharapkan dari dipenuhinya suatu perjanjian (expectation loss).

Dalam Pasal 1338 KUHPdt, disebutkan bahwa perjanjian berlaku sebagai undangundang bagi pihak-pihak yang terlibat atau terikat di dalamnya (pacta sunt servanda). Suatu perjanjian yang dibuat akan melahirkan kewajiban sekaligus hak bagi pihak-pihak yang mengikatkan diri di dalamnya. 
Munculnya sengketa dari suatu perjanjian pada dasarnya disebabkan oleh beberapa keadaan, yaitu adanya cacat (baik nyata maupun tersembunyi) dalam perjanjian, wanprestasi (cidera janji) dan perbuatan melawan hukum (onrechtmatigedaad). Perikatan yang lahir, baik dari perjanjian maupun karena ditetapkan oleh undangundang melahirkan hak dan kewajiban di antara pihak-pihak yang terikat di dalamnya. Jika salah satu pihak tidak mematuhi klausul dalam perjanjian, maka akan muncul sengketa di antara para pihak. Pun demikian, jika dalam suatu keadaan seseorang melakukan suatu tindakan yang secara melawan hukum telah menyebabkan kerugian pada pihak lain, maka akan terjadi sengketa karena undang-undang telah menetapkan hal tersebut.

Perlindungan hukum kontrak di Indonesia pada dasarnya mengacu pada satu tujuan, yaitu mengembalikan atau memulihkan hak-hak pihak yang dirugikan dalam suatu perjanjian. Pemulihan hak-hak para pihak akibat tidak ditepatinya suatu perjanjian (breach of contract) didasarkan pada adanya kerugian yang diderita salah satu pihak berdasarkan expectation loss atau hilangnya keuntungan yang diharapkan maupun kerugian nyata yang diderita (reliance loss). Di sini terlihat adanya pergeseran pemahaman dari doktrin klasik mengenai ganti rugi atas cidera janji. Semula, doktrin klasik membedakan secara tegas lembaga ganti rugi akibat cidera janji, yaitu expectation loss bukan reliance loss. Menurut doktrin klasik, reliance loss adalah lembaga ganti rugi atas perbuatan melawan hukum pihak-pihak yang sebelumnya tidak terikat suatu perjanjian tertentu.

Dalam tradisi common law (doktrin klasik mengenai hukum kontrak), konsepkonsep tersebut merupakan implikasi dari hubungan sebab akibat. Cidera janji dikenal dengan istilah breach of contract yang menimbulkan expectation loss dan pemulihan haknya didasarkan pada doktrin "put the plaintiff to the position if he would have been in had the contract been performed', yaitu menempatkan Penggugat pada posisi seandainya perjanjian dilaksanakan oleh Tergugat (Suharnoko, 2008). Sementara itu, perbuatan melawan hukum disebut dengan tort, yaitu perbuatan yang bertentangan norma hukum maupun norma kepatutan dan kesusilaan di masyarakat. Dalam tort, para pihak sebelumnya tidak terikat dalam perjanjian, namun karena suatu peristiwa yang lahir dari perbuatan atau pembiaran salah satu pihak menyebabkan kerugian nyata pada pihak lain. Disinilah kemudian konsep tort melahirkan akibat hukum berupa penggantian kerugian nyata atau reliance loss dari pihak yang menimbulkan kerugian kepada pihak yang menderita kerugian.

Doktrin klasik mengenai hukum kontrak memang tegas membedakan hal-hal mendasar mengenai perjanjian dan akibat hukumnya. Sebagai pengantar pembahasan bagian ini, penulis mengidentifikasi setidaknya dua hal utama dalam doktrin klasik hukum kontrak, baik di Negara yang menganut civil law maupun common law, yaitu:

1) Perjanjian berbeda dengan pra kontrak atau pra perjanjian (sering disebut pula dengan negosiasi atau memorandum of understanding). Perjanjian memuat consideration atau prestasi yang tegas dan disepakati sementara dalam pra kontrak, tidak ada consideration melainkan promise atau janji satu pihak kepada pihak lain yang menimbulkan harapan akan ditandatanganinya suatu perjanjian. Perbedaan tersebut membawa akibat hukum berbeda. Pelanggaran terhadap perjanjian menyebabkan ia dapat diminta pertanggungjawaban mengganti kerugian yang diderita pihak lain, sementara pelanggaran atau menarik janji dalam pra kontrak tidak menyebabkan yang bersangkutan dapat dimintai pertanggungjawaban atas kerugian yang diderita pihak lain karena memang belum ada kontrak yang disepakati;

2) Doktrin klasik membedakan secara t e g a s le m b a a m e m i $\mathrm{ta}$ pertanggungjawaban akibat cidera janji atau breach of contract dengan pertanggungjawaban akibat perbuatan melawan hukum atau tort. Menurut 
doktrin klasik, dalam suatu perjanjian, kerugian yang diderita oleh salah satu pihak adalah "hilangnya keuntungan yang diharapkan" atau expectation loss, sehingga untuk menuntut ganti kerugian tersebut, maka lembaga yang digunakan adalah breach of contract, bukan tort. Dalam sejarahnya, Pengadilan di Indonesia cenderung mengikuti doktrin ini sehingga jika tuntutan meminta ganti rugi atas pelanggaran suatu perjanjian didasarkan pada perbuatan melawan hukum (tort, onrechtmatige daad) atau mencampur aduk cidera janji dengan perbuatan melawan hukum, maka gugatan tersebut dianggap cacat formil dan dinyatakan tidak dapat diterima.

Perlindungan hukum kontrak di Indonesia, sesuai dengan karakter civil law, mengedepankan aspek kepastian hukum. Hal ini terlihat dari beberapa putusan Pengadilan yang mendasarkan pada doktrin klasik hukum kontrak yang membedakan secara tegas perbuatan melawan hukum dengan cidera janji serta menegasi adanya akibat hukum mengikat bagi janji-janji pra kontrak. Yurisprudensi pada mulanya membedakan secara sifat dan akibat hukum wanprestasi dengan perbuatan melawan hukum. Implikasinya, jika suatu gugatan didasarkan pada adanya hubungan kontraktual, maka posita dan petitum gugatan harus menggambarkan wanprestasi, bukan perbuatan melawan hukum. Jika menggunakan dasar perbuatan melawan hukum dalam gugatan atau mencampur wanprestasi dengan perbuatan melawan hukum, maka gugatan dianggap cacat formil.

$\mathrm{Nam} \mathrm{un} \mathrm{demikian,} \mathrm{d} \mathrm{a} 1$ a m perkembangannya, terjadi pergeseran pemikiran mengenai dasar gugatan pelanggaran suatu perjanjian (breach of contract). Mahkamah Agung melakukan terobosan dengan tidak mempertentangkan lagi sifat dan akibat dari perbuatan melawan dengan cidera janji dalam suatu hubungan kontraktual (perjanjian). Kasus gugatan perjanjian distributorship antara PT. Dua Berlian dengan Lee Kum Kee co, ltd. merupakan gambaran bagaimana perbuatan melawan hukum mendasari gugatan pelanggaran perjanjian yang dilakukan secara diam-diam (silent agreement).

Pada tahun 1987 tercapai kesepakatan antara Lee Kum Kee co. Itd dengan PT. Dua Berlian Jakarta. PT. Dua Berlian Jakarta ditunjuk oleh Lee Kum Kee untuk menjadi distributor tunggal saos makanan merek Lee Kum Kee di seluruh wilayah Indonesia dengan cara mengimpor menggunakan fasilitas letter of credit oleh PT. Dua Berlian Jakarta. Perjanjian distributorship ini berlaku hingga Januari 1993. Meski pada kenyataannya perjanjian berlaku sampai Januari 1993, namun setelahnya Lee Kum Kee tetap mengirimkan produk saosnya kepada PT. Dua Berlian Jakarta dan PT. Dua Berlian Jakarta menerimanya dengan menerbitkan puluhan letter of credit yang berlangsung sampai dengan Juni 1994. Pada Juni 1994 ini terjadi ketidaksepahaman antara Lee Kum Kee dengan PT. Dua Berlian Jakarta yang berakibat Lee Kum Kee memutuskan kontrak dengan PT. Dua Berlian Jakarta dan sekaligus menunjuk distributor baru, yaitu PT. Promex. Pemutusan perjanjian secara sepihak ini dianggap oleh PT. Dua Berlian Jakarta sebagai perbuatan melawan hukum dan menimbulkan kerugian, baik kerugian operasional (reliance loss) sejumlah $\mathrm{Rp}$. 1.585.322.135,-, hilangnya keuntungan yang diharapkan sejumlah Rp. 11.834.129.362,dan kerugian akibat kehilangan nama baik sejumlah Rp. 10.000.000.000,- (Suharnoko, 2008).

Perkara ini diperiksa dalam tiga tahap peradilan, peradilan tingkat pertama, banding, dan kasasi. Di Pengadilan tingkat pertama, Pengadilan Negeri Jakarta Utara mengabaikan eksepsi dari Tergugat yang menyatakan bahwa gugatan kabur karena dasar gugatan adalah pelanggaran perjanjian namun gugatan Penggugat justeru menuntut ganti rugi atas dasar perbuatan melawan. $\mathrm{P} u \mathrm{tu}$ s a $\mathrm{n}$ d e $\mathrm{ng}$ a $\mathrm{n}$ e g i s t e $\mathrm{r}$ 2/Pdt.G/1995/PN.Jkt.Ut. mengabulkan gugatan Penggugat (PT. Dua Berlian Jakarta) dengan menyatakan Lee Kum Kee melakukan perbuatan melawan hukum. Akan tetapi, putusan ini dibatalkan di tingkat banding dengan register putusan Nomor 301/Pd/1996/PT.DKI dengan pertimbangan 
bahwa pemutusan hubungan keagenan Tergugat terhadap Penggugat bukan merupakan perbuatan melawan hukum penunjukan suatu agen merupakan perbuatan sepihak dan pihak penunjuk dapat memutuskan secara sepihak keagenan dimaksud.

Pada tingkat kasasi, Mahkamah Agung membatalkan putusan banding yang membatalkan putusan pengadilan tingkat pertama. Mahkamah Agung berpendapat bahwa judex facti dalam hal ini Pengadilan Tinggi DKI Jakarta salah dalam menerapkan hukum. Antara Penggugat dan Tergugat terjadi perjanjian secara diam-diam (silent agreement), karena setelah berakhirnya perjanjian distributorship sesuai dengan jangka waktu yang tetulis, Tergugat tetap mengirimkan produknya kepada Penggugat selama lebih dari satu tahun. Dengan demikian, antara Penggugat dan Tergugat dianggap tetap melanjutkan suatu perjanjian distributorship, meskipun menurut formil perjanjian, perjanjian dimaksud telah berakhir. Tindakan pemutusan secara sepihak oleh Tergugat secara nyata menimbulkan kerugian besar terhadap Penggugat yang telah menginvestasikan modal dalam jumlah besar. Pemutusan perjanjian secara sepihak bertentangan dengan perundang-undangan dan kepatutan dalam kegiatan bisnis. Atas dasar itu, Tergugat (Lee Kum Kee) dianggap telah melakukan perbuatan melawan hukum dan karenanya wajib mengganti sejumlah kerugian yang diderita Penggugat ((Suharnoko, 2008).

Terlihat jelas adanya pergeseran pemikiran mengenai relasi antara pelanggaran kontrak dengan perbuatan melawan hukum. Mahkamah Agung mengintrodusir doktrin hukum kontemporer yang tidak lagi membedakan secara tegas pelanggaran kontrak atau cidera janji (wanprestasi, breach of contract) dengan perbuatan melawan hukum. Adanya hubungan kontraktual bukan lagi menjadi penghalang diajukan gugatan perbuatan melawan hukum. Lagi pula, dalam pelanggaran perjanjian, sangat terbuka kemungkinan kerugian yang ditimbulkan merupakan kerugian nyata atau kerugian akibat kegiatan operasional (reliance loss), disamping hilangnya keuntungan yang diharapkan (expectation loss).

M. Yahya Harahap mengemukakan bahwa wanprestasi pada prinsipnya merupakan specific genus (bentuk khusus) dari perbuatan melawan hukum. Wanprestasi dalam perjanjian kredit dapat dipandang sebagai perbuatan yang bertentangan atau melawan hak kreditur atas pembayaran sejumlah piutangnya (M. Yahya Harahap, 1986). Sifat melawan hak inilah yang merupakan ratio legis dari berkembanganya suatu pemahaman yang tidak lagi membedakan secara tegas antara perbuatan melawan hukum dengan cidera janji.

Penafsiran secara luas atas pengertian perbuatan melawan hukum sejalan dengan perkembangan teori atau doktrin dalam hukum kontrak (perjanjian) bahwa perjanjian harus dibuat dengan iktikad baik yang berarti harus memperhatikan asas kepatutan. Perjanjian yang memuat prestasi yang tidak berimbang tidak selaras dengan prinsip kepatutan sehingga klausula yang tidak berimbang tersebut dapat dinyatakan batal demi hukum dan tidak mengikat para pihak yang terlibat dalam perjanjian (Suharnoko, 2008).

Salah satu isu yang sangat menarik terkait perlindungan hukum kontrak adalah perlindungan konsumen. Perlindungan konsumen merupakan konsep yang lahir dari kelaziman fakta yang menunjukkan bahwa hubungan antara produsen dan konsumen sering kali tidak seimbang dengan konsumen sebagai pihak yang paling sering berada dalam kedudukan lemah atau inferior.

Undang-Undang Nomor 8 Tahun 1999 tentang Perlindungan Konsumen memberikan pengaturan yang dapat dikatakan cukup lengkap dan protektif terhadap hak-hak konsumen. Salah satu penekanan dalam Undang-Undang ini adalah dilarangnya mencantumkan beberapa klausula dalam kontrak baku yang dianggap tidak adil dan melanggar hak-hak konsumen serta tidak sesuai dengan prinsip-prinsip kepatutan.

Eksistensi kontrak baku (standard contract) memang telah diakui dan diterima dalam hukum Indonesia. Namun demikian, kontrak baku yang dibuat atau disusun secara 
sepihak sangat rentan dengan muatan kalusula yang berat sebelah dan memberatkan konsumen. Karena itu, Pasal 18 UndangUndang Nomor 8 Tahun 1999 menegaskan larangan-larangan klausula dalam kontrak baku, yaitu klausula yang:

1) Menyatakan pengalihan tanggung jawab (klausula eksonerasi, exemption clause);

2) Menyatakan bahwa pelaku usaha berhak menolak penyerahan kembali barang yang dibeli konsumen;

3) Menyatakan bahwa pelaku usaha berhak menolak penyerahan kembali uang yang dibayarkan atas barang dan/atau jasa yang dibeli oleh konsumen;

4) Menyatakan pemberian kuasa dari konsumen kepada pelaku usaha baik secara langsung maupun tidak langsung untuk melakukan segala tindakan sepihak yang berkaitan dengan barang yang dibeli oleh konsumen secara angsuran;

5) Mengatur perihal pembuktian atas hilangnya kegunaan barang atau pemanfaatan jasa yang dibeli oleh konsumen;

6) Memberi hak kepada pelaku usaha untuk mengurangi manfaat jasa atau mengurangi harta kekayaan konsumen yang menjadi obyek jual beli jasa;

7) Menyatakan tunduknya konsumen kepada peraturan yang berupa aturan baru, tambahan, lanjutan dan/atau pengubahan lanjutan yang dibuat sepihak oleh pelaku usaha dalam masa konsumen memanfaatkan jasa yang dibelinya;

8) Menyatakan bahwa konsumen memberi kuasa kepada pelaku usaha untuk pembebanan hak tanggungan, hak gadai, atau hak jaminan terhadap barang yang dibeli oleh konsumen secara angsuran.

Klausula-klausula tersebut merupakan klausula yang bersifat melawan hak-hak subjektif konsumen, baik yang ditetapkan oleh undang-undang maupun menurut kepatutan. Oleh karena sifatnya melawan hak (onrechtmatigeheid), maka klausula-klausula tersebut jika dicantumkan dalam kontrak baku antara produsen dan konsumen batal demi hukum (nietig).

\section{b. Perlindungan hukum terhadap pra kontrak}

Seperti yang telah dikemukakan tersebut di atas bahwa dalam doktrin kontrak modern, para pihak yang akan melakukan suatu perjanjian, terlebih dalam kontrak bisnis skala besar, lazim dilakukan negosiasi pra kontrak atau kontrak pendahuluan (preliminary contract). Negosiasi pra kontrak pada prinsipnya bertujuan menjajagi berbagai kemungkinan atas rencana diadakannya perjanjian di antara para pihak. Dalam tahap ini sering muncul atau disampaikan berbagai janji satu pihak kepada pihak lain dengan harapan pihak lain setuju untuk mengadakan perjanjian sebagai tindak lanjut negosiasi. Pihak lain yang dijanjikan menaruh harapan atas janji tersebut yang ditandai dengan kesediaan melakukan beberapa tindakan hukum (rechtshandeling), misalnya menyerahkan uang atau barang sebagai tanda jadi. Permasalahan muncul ketika salah satu pihak yang menaruh kepercayaan dan telah menyerahkan sejumlah uang sebagai prasyarat dalam melakukan perjanjian kemudian ternyata tidak memperoleh hakhak yang diharapkan sebagaimana dijanjikan oleh pihak lain dalam negosiasi. Apakah pihak yang dirugikan dapat meminta ganti kerugian terhadap pihak yang mengingkari janjinya sementara di antara mereka belum ada kontrak atau perjanjian yang ditandatangani?.

Permasalahan mengenai akibat hukum pra kontrak di Indonesia tergambar dalam kasus Jeffry Binalay dkk melawal Kepala Staf Angkatan Laut. Posisi kasusnya adalah sebagai berikut:

- Jeffry Binalay dkk adalah penghuni dari rumah dinas TNI-AL. Almarhum orang tua Jeffry Binalay dkk adalah purnawirawan TNI-AL. Mereka menghuni rumah dinas TNI-AL berdasarkan Surat Izin Perumahan (SIP) yang dikeluarkan oleh Dinas TNIAL.Pada tahun 1992 KASAL mengeluarkan Surat Keputusannya Nomor : 1212/III/1992 tanggal 23 Maret 1992 yang menetapkan bahwa rumah Dinas TNI-AL Di Wilayah Jakarta 
Sebagai Rumah Dinas TNI-AL Non Strategis.

- Pertimbangan KASAL mengeluarkan surat keputusan Nomor : 1212 tersebut adalah untuk meningkatkan kesejahteraan anggota TNI AL dan umumnya rumah dinas tersebut sudah berusia lebih dari tiga puluh tahun dan ditempati sebagian besar oleh para Purnawirawan/Warakawuri. Surat keputusan KASAL diatas kemudian dijadikan dasar hukum untuk surat-surat keputusan dan surat-surat serta kebijakan-kebijakan yang lain sebagai pedoman pelaksanaan proses pelepasan/jual beli rumah dinas;

- Atas surat keputusan diatas, TNI-AL mengeluarkan kebijakan untuk melepaskan rumah-rumah dinas tersebut kepada para anggota yang menghuni rumah dinas tersebut. Selanjutnya kebijakan ini telah diteruskan kepada Menhankam/Pangab. Kakanwil Dirjen Anggaran Jakarta menunjuk suratnya telah menyetujui dan Kepala BPN Jakarta Utara menunjuk suratnya, menyatakan bahwa proses pelepasan rumah dinas tersebut dapat dilaksanakan;

- Atas kebijakan tersebut, anggota yang menghuni rumah dinas tersebut menyambutnya dengan suka cita dan menindak lanjuti dengan menyiapkan serta melengkapi berkas-berkas yang disyaratkan oleh TNI-AL, diantaranya adalah mengajukan permohonan secara tertulis kepada TNI-AL hingga melakukan pengukuran atas tanah yang dihuninya, yang dilakukan oleh TNI-AL bekerjasama dengan BPN Jakarta Utara dll;

- Namun hingga diawal tahun 2003 proses pelepasan rumah dinas tersebut belum juga dapat terealisasikan, bahkan dengan surat keputusannya Nomor : Skep/344/II/2003 tanggal 24 Pebruari 2003, Tentang Peraturan Pokok Perumahan Dinas TNI Angkatan Laut, KASAL mengeluarkan kebijakan, bagi anggota yang telah pensiun, selambat- lambatnya tanggal 24 Pebruari 2007 harus sudah meninggalkan rumah dinas yang dihuninya. Dengan surat keputusan diatas, maka perihal proses pelepasan rumah dinas yang sudah dilakukan menjadi tidak jelas;

- Atas hal-hal diataslah Para Penggugat, Jeffry Binalay dkk menggugat KASAL dkk ke Pengadilan Negeri Jakarta Utara; - Dalam putusannya tanggal 8 Oktober 2007 yang diucapkan tanggal 9 Oktober 2007, Majelis Hakim Pengadilan Negeri Jakarta Utara "Menolak gugatan para Penggugat untuk seluruhnya", dimana pada salah satu pertimbangannya Majelis Hakim menyatakan “...akan tetapi berdasarkan fakta-fakta yang terungkap di persidangan telah ternyata bahwa antara para Penggugat dengan para Tergugat tidak ada kesepakatan atau perjanjian jual beli rumah dinas, maka menurut Majelis Hakim para Tergugat..."

Putusan Pengadilan pada tingkat pertama hingga peninjauan kembali menunjukkan bahwa sampai tahun diputuskannya perkara tersebut, pengadilan Indonesia masih menganut doktrin hukum kontrak klasik yang mengedepankan aspek kepastian hukum. Dalam kasus ini, oleh karena belum ada perjanjian yang disepakati dan/atau ditandatangani oleh Jeffry dkk dengan KASAL, maka dianggap belum ada hal mengikat bagi keduanya dan tidak dipenuhinya janji-janji untuk melakukan penjualan tanah rumah dinas seperti yang dijanjikan oleh KASAL bukanlah suatu perbuatan melawan hukum (hak), karenanya K A S A L tidak dapat dimintai pertanggungjawaban. Hal ini jelas mengabaikan kerugian yang diderita oleh Jeffry dkk yang telah menaruh pengharapan kepada KASAL dengan telah melakukan beberapa tindakan hukum untuk kepentingan pembebasan tanah.

Doktrin hukum klasik menekankan bahwa asas iktikad baik hanya dapat diterapkan dalam situasi dimana perjanjian telah memenuhi syarat hal tertentu. Implikasinya, ajaran ini tidak melindungi pihak yang menderita kerugian dalam tahap 
pra kontrak atau tahap perundingan karena dalam tahap ini perjanjian belum memenuhi syarat "hal tertentu" (Suharnoko, 2008).

Seperti yang telah dikemukakan sebelumnya bahwa dalam negosiasi pra kontrak, sangat memungkinkan adanya janjijanji yang disampaikan oleh salah satu pihak yang berakibat pihak lain menaruh kepercayaan dan pengharapan bahwa kelak perjanjian akan disepakati dan ditandatangani. Di Negara common law telah berkembang doktrin promissory estoppels, yaitu suatu doktrin yang melarang pihak yang telah berjanji menarik kembali janjinya tanpa alasan yang dapat dibenarkan menurut hukum dan/atau kepatutan. Dengan doktrin ini, maka pihak-pihak dalam negosiasi tidak boleh mengingkari janjinya begitu saja tanpa ada alasan yang sah dan patut, terlebih jika hal itu nyata-nyata menimbulkan kerugian pada pihak lain. Indonesia tampaknya belum menerapkan konsep ini secara utuh dan cenderung masih berkutat pada doktrin klasik yang menganggap belum ada akibat hukum dari suatu negosiasi. Padahal, ketentuan mengenai iktikad baik dalam KUHPerdata seharusnya dapat menjadi pintu masuk dalam menerapkan doktrin promissory estoppels untuk melindungi kepentingan pihak yang dirugikan akaibat janji yang tidak dilaksanakan oleh pihak lain.

\section{Simpulan}

Sebagai penutup, penulis menyimpulkan beberapa hal berikut:

1. Perlindungan hukum terhadap kontrak (perjanjian) di Indonesia didasarkan pada asas kepastian hukum yang menekankan formalitas dari suatu perjanjian. Namun demikian, dalam perkembangannya, perlindungan hukum kontrak telah memperhatikan secara lebih signifikan aspek keadilan substantif. Terkait dengan kontrak baku, perlindungan hukum kontrak lebih menekankan prinsip keadilan dan/atau keseimbangan kedudukan, hak, dan kewajiban antara produsen dengan konsumen maupun kreditur dengan debitur. Klausula dalam kontrak baku tidak boleh melanggar ketentuan Pasal 18 Undang-Undang
Nomor 8 Tahun 1999 tentang Perlindungan Konsumen;

2. Terkait dengan akibat hukum pra kontrak, praktik peradilan di Indonesia masih berpegang pada doktrin hukum klasik yang membedakan secara tegas akibat hukum suatu perjanjian dengan pra kontra (pra perjanjian). Padahal. Dalam banyak kasus, ada pihak-pihak yang dirugikan dalam pra kontrak akibat tidak dipenuhinya janji oleh pihak lain. Seharusnya konsep perlindungan hukum kontrak di Indonesia mengadopsi doktrin kotemporer yang mengakui adanya akibat hukum dari pra kontrak dalam rangka mewujudkan keadilan substantif.

\section{DAFTAR PUSTAKA}

Ali, Achmad, Menguak Tabir Hukum, Jakarta: Chandra Pratama, 1996.

Black, Henry Campbell, Black's Law Dictionary, Fourth Edition, Minnesota: West Publishing Co., 1968.

Harahap, M. Yahya, Segi-Segi Hukum Perjanjian, Bandung: Alumni, 1986.

Kartini Muljadi, Kartini \& Widjaja, Gunawan, Perikatan yang Lahir dari Perjanjian. Jakarta: Rajawali Pers. 2003.

Salim HS, et.al, Perancangan Kontrak \& Memorandum of Understanding (MoU), Jakarta Sinar Grafika, 2008.

Sasongko, Wahyu, KetentuanKetentuan Pokok Hukum Perlindungan Konsumen, Lampung: Unila, 2007.

Subekti dan Tjitrosudibio, Kitab Undang-Undang Hukum Perdata, Jakarta: PT. Pradnya Paramita, 2002.

Suharnoko, Hukum Perjanjian: Teori dan Analisa Kasus, Jakarta: Kencana, 2008.

---------, Kompilasi Hukum

Ekonomi Syariah (Edisi Revisi), Jakarta: Pusat Pengkajian Hukum Islam dan Masyarakat Madani, 2009.

Syahrani, Riduan, Seluk Beluk dan Asas-Asas Hukum Perdata, Bandung: 56Alumni, 2006. 